\title{
DAYA SIMPAN BENIH JABON PUTIH [Neolamarckia cadamba (Roxb.) Bosser] BERDASARKAN POPULASI DAN KARAKTERISTIK BENIH
}

\author{
Seed Storability of Jabon Putih [Neolamarckia cadamba (Roxb.) Bosser] Base on \\ Populations and Seed Characteristics
}

\author{
Evayusvita Rustam ${ }^{1}$, Tatiek K. Suharsi' ${ }^{2}$, M. Rahmad Suhartanto ${ }^{2}$ dan/and \\ Dede J. Sudrajat ${ }^{1}$ \\ ${ }^{1}$ Balai Penelitian dan Pengembangan Teknologi Perbenihan Tanaman Hutan \\ J1. Pakuan Ciheuleut PO BOX 105, Bogor, Jawa Barat, Indonesia \\ ${ }^{2}$ Departemen Agronomi dan Holtikultur, Fakultas Pertanian, Institut Pertanian Bogor \\ Jl. Meranti, Kampus IPB Darmaga, Bogor, Jawa Barat, Indonesia
}

Tanggal diterima: 10 April 2017; Tanggal direvisi: 31 Mei 2017; Tanggal disetujui: 22 Juni 2017

\begin{abstract}
Jabon putih [Neolamarckia cadamba (Roxb.) Bosser] has been cultivated in large scale. However it is constrained by the availability of high quality seeds and seed storability information. This study aimed to identify seed storability of jabon putih based on populations and seed morpho-physiological characteristics. Seeds were collected from eight populations, located in eight provinces. Population was a single factor in a completely randomized design for testing the germination characteristics (germination capacity, germination uniformity, germination speed, mean germination time and germination value) before and after storage. Geo-climate and soil macro elements were used as parameters to examine the correlation between environmental factors and seed characteristics before and after storage. Population was significantly correlated with germination characteristics, before and after storage for 54 months. The results indicated that seeds from Pomalaa population had the best germination characteristics, while those from Ogan Kemiring Ilir had the worst germination characteristics. Based on moisture content and storability, jabon putih seed could be categorized as orthodox that can be stored in long time at low temperatures with low moisture content. Geo-climate and soil macro element were not significantly correlated with germination. This result indicated that genetic factor had high contribution to seed storability of jabon putih.
\end{abstract}

Key word : Genetic factor, morpho-physiological, ortodox seed, storage

\begin{abstract}
ABSTRAK
Jabon putih [Neolamarckia cadamba (Roxb.) Bosser] telah banyak dibudidayakan dalam skala luas, namun terkendala dengan ketersediaan benih bermutu dan belum adanya informasi daya simpan benih. Penelitian ini bertujuan untuk mengidentifikasi karakteristik daya simpan benih jabon putih berdasarkan populasi dan karakteristik morfo-fisiologi benih. Benih dikumpulkan dari delapan populasi yang terletak di delapan provinsi. Populasi menjadi faktor tunggal dalam rancangan acak lengkap untuk menguji karakteristik perkecambahan (daya berkecambah, keserempakan tumbuh, kecepatan berkecambah, rata-rata waktu berkecambah dan nilai perkecambahan) sebelum dan setelah penyimpanan. Geo-klimat dan unsur makro tanah merupakan parameter yang dipakai untuk menguji korelasi antara faktor lingkungan dan karakteristik perkecambahan benih sebelum dan sesudah disimpan. Perbedaan asal benih atau populasi berpengaruh nyata terhadap perkecambahan benih sebelum dan setelah disimpan selama 54 bulan. Benih dari populasi Pomalaa (Sulawesi Tengah) mempunyai karakteristik perkecambahan terbaik sedangkan benih dari populasi Ogan Kemiring Ilir (Sumatera Selatan) mempunyai karakteristik perkecambahan terendah. Berdasarkan tingkat kadar air dan daya simpannya, benih jabon putih dapat dikategorikan sebagai benih ortodoks yang mampu disimpan lama pada suhu dan kadar air rendah. Sebagian besar faktor geo-klimat dan unsur makro tanah tidak berkorelasi nyata dengan perkecambahan benih baik sebelum maupun setelah disimpan. Hasil penelitian ini memberi indikasi bahwa faktor genetik berkontribusi besar dalam mempengaruhi perbedaan daya simpan benih jabon putih.
\end{abstract}

Kata kunci: Benih ortodoks, faktor genetik, morfo-fisiologi, penyimpanan 


\section{PENDAHULUAN}

Jabon putih (Neolamarckia cadamba (Roxb.)) Bosser, sinonim Anthocephallus cadamba (Roxb.) Miq. merupakan jenis potensial cepat tumbuh dengan sebaran yang sangat luas. Jenis ini menghasilkan kayu yang dapat dimanfaatkan untuk kayu lapis, konstruksi, pulp, papan serat, papan partikel (Sudrajat, 2015) dan bahan obatobatan seperti anti mikroba (Acharyya, Rathore, Kumar, \& Panda, 2011) anti bakteri (Mishra, \& Siddique, 2011). Pada saat ini jabon putih sudah banyak dibudidayakan baik dalam skala kecil dalam bentuk hutan rakyat terutama di Jawa dan Kalimantan Selatan, maupun skala besar di beberapa daerah seperti Sumatera Utara, Riau dan Kalimantan Tengah (Kallio, Krisnawati, Rohadi, \& Kanninen, 2011; Krisnawati, Kallio, \& Kanninen, 2011; Irawan \& Purwanto, 2014)

Salah satu kendala dalam budidaya jabon putih adalah penyediaan benih bermutu tinggi yang sering kali sulit didapatkan selain teknik perkecambahannya yang relatif lebih sulit dibandingkan benih tanaman lainnya yang lebih besar (Sudrajat, 2013). Selain itu, teknik penyimpanan benih pun masih menjadi kendala. Menurut (Mansur, 2012), benih jabon putih mengalami penurunan daya berkecambah setelah disimpan 2-3 bulan sehingga tidak disarankan untuk disimpan dalam jangka waktu yang lama. Di lain pihak (Yuniarti \& Nurhasybi, 2015) menyatakan bahwa benih jabon putih dikategorikan sebagai benih ortodoks dan memungkinkan memiliki daya simpan lama dalam kondisi kadar air rendah 5-8\%. Namun informasi mengenai daya simpan benih jabon putih dalam kurun waktu yang lama masih belum ada. Daya simpan tersebut diduga akan berbeda antar populasi mengingat jabon putih mempunyai keragaman genetik yang cukup tinggi dengan sebaran tumbuh yang luas (Sudrajat, Siregar, Khumaida, Siregar, \& Mansur, 2015; Sudrajat, 2016).

Daya simpan benih dipengaruhi oleh berbagai faktor diantaranya faktor genetik (Sudrajat \& Nurhasybi, 2016), ekologi tempat tumbuh (Yasaka et al., 2008), proses penanganan benih (Shelar, Shaikh, \& Nikam, 2008; Khatun, Kabir, \& Bhuiyan, 2009), kondisi dan lama penyimpanan (Suszka et al., 2014). Secara fisik, antar kelompok benih dari tempat tumbuh berbeda memungkinkan terjadinya perbedaan watak dan morfologi benihnya sebagai pengaruh perbedaan lingkungan, keturunan (genetik) dan faktor pertumbuhan (Rawat \& Bakshi, 2011; Sudrajat, 2016) Beberapa penelitian menunjukkan adanya variasi daya simpan benih antar kelompok benih atau populasi seperti pada benih Swertia chirayita (Pradhan, \& Badola, 2012), benih Physaria sp. (Cruz, Walters, \& Dierig, 2013) dan benih Toona sinensis (Sudrajat \& Nurhasybi, 2016).

Penelitian bertujuan untuk mengetahui daya simpan benih jabon putih dari delapan populasi dan hubungannya dengan faktor karakteristik morfofisiologi benih sebelum disimpan. Diharapkan penelitian ini mampu memberikan informasi daya simpan dan teknik penyimpanan benih jabon putih.

\section{METODOLOGI}

\section{A. Lokasi Penelitian}

Bahan penelitian berupa buah jabon putih yang diunduh pada tahun 2012 dari delapan populasi alami (Tabel 1). Setiap populasi diwakili oleh 20 pohon induk dengan ciri-ciri pohon berpenampilan baik (tinggi, diameter) dibandingkan pohon sejenis di sekitarnya dan jarak antar pohon induk 50-100 m untuk menghindari pengambilan sampel benih berkerabat dekat. Buah yang diunduh 
merupakan buah yang telah masak secara fisiologis yang dicirikan dengan perubahan warna dari hijau ke hijau kekuningan hingga kuning. Pengecambahan benih dilakukan di rumah kaca Balai Penelitian dan Pengembangan Tek-nologi Perbenihan Tanaman Hutan.

\section{B. Metode}

\section{Pengumpulan data lapangan dan pengukuran benih}

Data lapangan yang dikumpulkan meliputi letak geografis, curah hujan, suhu rata-rata tahunan, ketinggian tempat dan tingkat kesuburan tanah. Pengambilan sampel tanah dilakukan pada kedalaman $20 \mathrm{~cm}$ dari permukaan tanah masing-masing 3 titik dengan jarak 50$100 \mathrm{~m}$ di bawah setiap pohon induk. Sampel tanah kemudian dicampur per populasi. Sampel tanah dari setiap populasi dianalisis tingkat kesuburannya di Laboratorium Tanah dan Tanaman, SEAMEO BIOTROP (http://www. biotrop.org), Bogor.
Pengukuran morfo-fisiologi benih dilakukan di laboratorium pengujian benih Balai Penelitian dan Pengembangan Tek-nologi Perbenihan Tanaman Hutan, Bogor. Buah jabon putih yang telah masak secara fisiologis diekstraksi menggunakan metode ekstraksi basah (Sudrajat, 2013). Benih yang terkumpul kemudian dikering-anginkan selama tiga hari. Benih tersebut dicampur dengan berat sama dari setiap pohon induk untuk setiap populasi. Pe-ngukuran morfologi benih dilakukan dengan menggunakan mikroskop cahaya (Zeiss discovery V.8 stereo) terhadap panjang dan lebar benih, sedangkan untuk berat 1.000 butir benih dilakukan dengan menimbang 100 butir benih sebanyak delapan ulangan dan selanjutnya ditransformasikan ke dalam berat 1.000 butir benih (ISTA, 2012). Data yang digunakan merupakan data sekunder (Sudrajat 2015).

Tabel (Table) 1. Deskripsi geo-klimat populasi jabon putih (Geo-climate description of white jabon populations)

\begin{tabular}{|c|c|c|c|c|c|}
\hline Populasi (Populations) & $\begin{array}{l}\text { Lintang } \\
\text { (Latitude) }\end{array}$ & $\begin{array}{c}\text { Bujur } \\
\text { (Longitude) }\end{array}$ & $\begin{array}{c}\text { Ketinggian } \\
\text { (Altitude) } \\
(\mathrm{m} \text { dpl) } \\
(m \text { asl })\end{array}$ & $\begin{array}{c}\text { Curah hujan } \\
\text { (Precipitation) } \\
\text { (mm/tahun) } \\
(\text { mm/years })\end{array}$ & $\begin{array}{c}\text { Suhu } \\
\text { (Temperature) } \\
\left({ }^{\circ} \mathrm{C}\right)\end{array}$ \\
\hline Kampar (Riau) & $00^{\circ} 18^{\prime} \mathrm{U}$ & $100^{\circ} 57^{\prime} \mathrm{T}$ & 50 & 3000 & 26,5 \\
\hline $\begin{array}{l}\text { Ogan KomeringIlir } \\
\text { (Sumatera Selatan) }\end{array}$ & $03^{\circ} 12^{\prime} \mathrm{S}$ & $104^{\circ} 51^{\prime} \mathrm{T}$ & 23 & 2500 & 27,1 \\
\hline Garut (Jawa Barat) & $07^{\circ} 26^{\prime} \mathrm{S}$ & $107^{\circ} 42^{\prime} \mathrm{T}$ & 628 & 2500 & 27,0 \\
\hline $\begin{array}{l}\text { Nusa Kambangan } \\
\text { (Jawa Tengah) }\end{array}$ & $07^{\circ} 43^{\prime} \mathrm{S}$ & $108^{\circ} 55^{\prime} \mathrm{T}$ & 40 & 2500 & 28,0 \\
\hline $\begin{array}{l}\text { Alas Purwo } \\
\text { (Jawa Timur) }\end{array}$ & $08^{\circ} 38^{\prime} \mathrm{S}$ & $114^{\circ} 21^{\prime} \mathrm{T}$ & 33 & 1500 & 28,5 \\
\hline $\begin{array}{l}\text { Kapuas } \\
\text { (Kalimantan Tengah) }\end{array}$ & $01^{\circ} 00^{\prime} \mathrm{S}$ & $114^{\circ} 28^{\prime} \mathrm{T}$ & 147 & 2970 & 28,7 \\
\hline $\begin{array}{l}\text { Batu Hijau } \\
\text { (Nusa Tenggara Barat) }\end{array}$ & $08^{\circ} 58^{\prime} \mathrm{S}$ & $116^{\circ} 48^{\prime} \mathrm{T}$ & 53 & 2290 & 29,0 \\
\hline $\begin{array}{l}\text { Pomalaa } \\
\text { (Sulawesi Tengah) }\end{array}$ & $04^{\circ} 03^{\prime} \mathrm{S}$ & $121^{\circ} 39^{\prime} \mathrm{T}$ & 210 & 1780 & 28,0 \\
\hline
\end{tabular}




\section{Pengujian kadar air dan biokimia benih}

Kadar air benih sebelum dan setelah penyimpanan diukur dengan metode oven pada suhu $(103 \pm 2)^{0} \mathrm{C}$ selama $17 \mathrm{jam}$. Contoh kerja untuk kadar air dalam penelitian ini adalah 5 gram yang diulang sebanyak empat kali. Penghitungan kadar air benih mengacu pada ketentuan ISTA (2012). Pengujian kandungan biokimia benih dilakukan sebelum penyimpanan di Laboratorium Balai Penelitian Tanaman Rempah dan Obat, Bogor. Sebanyak $2 \mathrm{~g}$ benih ditimbang dan disiapkan untuk analisis karbohidrat, lemak dan protein. Kadar lemak ditentukan berdasarkan metode ekstraksi Soxhlet. Kadar protein ditentukan dengan menggunakan metode Kjeldahl, sedangkan karbohidrat total ditentukan berdasarkan metode different (Eshun, Amankwah, \& Barimah, 2013; Sudrajat \& Nurhasybi, 2016).

\section{Pengujian perkecambahan benih sebelum penyimpanan}

Pengujian perkecambahan dilaku-kan dengan metode uji di atas pasir (UDP) di rumah kaca. Pengujian dari setiap kelompok benih berjumlah empat ulangan dengan masing-masing ulangan 100 butir benih. Penghitungan perke-cambahan dilakukan terhadap kecam-bah yang telah memiliki sepasang daun yang membuka sempurna. Pengamatan dan perhitungan dilakukan setiap hari sampai hari ke-40 setelah tabur (Yuniarti, Kurniaty, \& Nurhasybi, 2015). Parameter yang diamati meliputi daya berkecambah (DB), keserempakan tum-buh (Кsт), kecepatan berkecambah (КСт), ratarata waktu berkecambah (RWB), nilai perkecambahan (NP) dengan ru-mus sebagai berikut (Gairola et al., 2011).

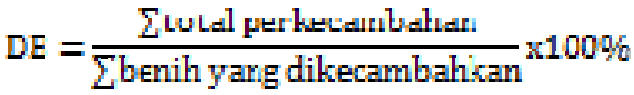

Kst $=\frac{\text { (EKecambah NK hari ke }-21)}{\text { Zbenihyang ditanam }} \times 100 \%$

$\mathrm{K}_{\mathrm{cT}}=\sum_{\mathrm{a}}^{\mathrm{n}} \frac{\text { hecambah normal ke }-\mathrm{i}}{\text { waktu pengamatanke }-\mathrm{i}}$

RWB $=\frac{\left(\mathrm{n}_{2}, \mathrm{~d}_{2}\right)+\left(\mathrm{n}_{\mathrm{z}}, \mathrm{d}_{2}\right)+\cdots+\left(\mathrm{n}_{\mathrm{i}}, \mathrm{d}_{\mathrm{i}}\right)}{\text { total benihyang berkecambah }}$

$\mathrm{NP}=\mathrm{PVXMDG}$

$\mathrm{PV}=\frac{\text { Q perkecambahan tertingeg }}{\sum \text { hari untuk mencapainya }}$

$M D G=\frac{\text { \% perkecambahan pada akhir pengamatan }}{\text { Hari perkecambahan terakhir }}$

Dimana: $\mathrm{NK}=$ jumlah kecambah normal, $\mathrm{n}=$ jumlah benih yang berkecambah pada hari ke-i, $\mathrm{d}=$ hari berkecambah, PV = puncak perkecambahan, $\mathrm{MDG}=$ rata-rata perkecambah harian.

\section{Penyimpanan dan pengujian benih setelah disimpan}

Kelompok benih dari delapan populasi dikemas dalam plastik kedap dan disimpan di refrigerator pada suhu $0-4^{\circ} \mathrm{C}$ dan kelembaban nisbi $40-50 \%$. Pengujian perkecambahan setelah penyimpanan benih dilakukan dengan me-tode dan parameter yang sama dengan pengujian perkecambahan sebelum penyimpanan.

\section{Rancangan penelitian dan analisis data}

Rancangan penelitian menggunakan Rancangan Acak Lengkap. Analisis ragam digunakan untuk menguji pengaruh popu-lasi terhadap parameterparameter daya simpan benih dari delapan populasi. Uji jarak Duncan digunakan bila populasi berpengaruh nyata terhadap parameter yang diuji. Korelasi sederhana (Pearson Correlation) digunakan untuk menemukan hubungan antar daya simpan dengan karakteristik benih sebelum disimpan dan 
parameter geo-klimat (curah hujan, ketinggian tempat, dan suhu rata-rata) populasi.

\section{HASIL DAN PEMBAHASAN}

\section{A. Hasil \\ 1. Viabilitas dan vigor benih jabon putih}

Perbedaan populasi berpengaruh nyata terhadap semua parameter perkecambahan benih jabon putih yang diuji baik sebelum maupun setelah di-simpan (kadar air, daya berkecambah, keresempakan tumbuh, kecepatan berkecambah, rata-rata waktu berkecambah dan nilai perkecambahan benih), kecuali untuk nilai kadar air setelah disimpan dan rata-rata waktu berkecambah sebelum disimpan (Tabel 2). Sebelum disimpan kadar air be-nih dari semua populasi berbeda nyata, yaitu berkisar antara 5,58$7,52 \%$, kadar air terendah benih berasal populasi Pomalaa dan kadar air tertinggi benih berasal dari populasi Kampar. Setelah penyimpanan kadar air mengalami penurunan untuk semua populasi dan menunjukkan nilai yang tidak berbeda nyata antar populasi. Persentase penurunan kadar air untuk masing-masing daerah berkisar antara 1,10-2,94\% (Gambar 1a).

Daya berkecambah benih, secara umum juga mengalami penurunan setelah penyimpanan 54 bulan. Benih yang berasal dari populasi Pomala dengan kadar air lebih rendah memiliki daya berkecambah tertinggi baik sebelum maupun setelah penyimpanan, yaitu $82,75 \%$ (sebelum penyimpanan) dan menurun sekitar 3,25\% menjadi 79,00\% (setelah penyimpanan). Penurunan daya berkecambah yang sangat drastis terjadi pada benih yang berasal dari Ogan Kemiring Ilir, yaitu dari $48,75 \%$ menjadi $2,50 \%$ setelah disimpan. Hanya benih dari populasi Batu Hijau yang daya berkecambah benihnya mengalami peningkatan sekitar 3,50\% dari daya berkecambah awal (Gambar 1b).

Tabel (Table) 2. Rekapitulasi F hitung pengaruh populasi terhadap parameter perkecambahan benih jabon putih sebelum dan setelah disimpan 54 bulan (Recapitulation of F-count on the effect of populations -to the germination parameters of $\mathrm{N}$. cadamba seeds before and after storage for 54 months)

\begin{tabular}{|c|c|c|}
\hline Parameter (Parameters) & $\begin{array}{l}\text { Sebelum simpan } \\
\text { (Before storage) } \\
(0 \text { Bulan) (Month) }\end{array}$ & $\begin{array}{l}\text { Setelah simpan } \\
\text { (After storage) } \\
\quad(54 \text { Bulan }) \\
(\text { Month })\end{array}$ \\
\hline Kadar air (Moisture content) & ** & ns \\
\hline Daya berkecambah (Germination capacity) & ** & ** \\
\hline Keserempakan tumbuh (Germination uniformity) & ** & $* *$ \\
\hline Kecepatan berkecambah (Germination speed) & ** & ** \\
\hline Rata-rata waktu berkecambah (Mean germination time) & $\mathrm{ns}$ & $*$ \\
\hline Nilai perkecambahan (Germination value) & $* *$ & $* *$ \\
\hline $\begin{aligned} \text { Keterangan (Remarks) : } & * *=\text { Berpengaruh nyata pada } \\
& \text { Berpengaruh nyata pada tingka } \\
& \text { berpengaruh nyata pada tingka }\end{aligned}$ & $\begin{array}{l}\text { ata } 1 \% \text { (Significa } \\
\text { (Significant at le } \\
\text { (No significant at } l\end{array}$ & $\begin{array}{l}\text { t level } 1 \%), *= \\
\text { f } 5 \% \text { ), ns = Tidak } \\
\text { of } 5 \% \text { ) }\end{array}$ \\
\hline
\end{tabular}




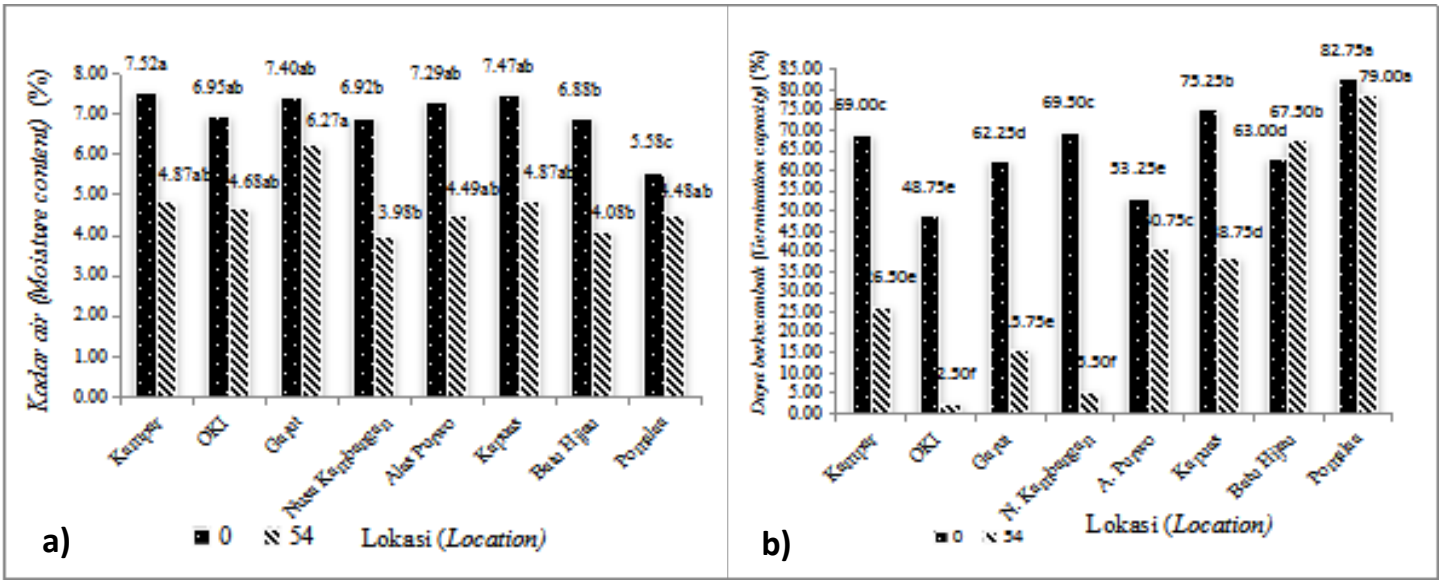

Keterangan (Remark) : Angka rata-rata yang diikuti oleh huruf sama menunjukkan bahwa nilai rata-rata tidak berbeda nyata pada tingkat nyata 5\% (Means followed by the same letters showed that mean are not significantly different at level of 5\%)

Gambar (Figure) 1. Perbedaan kadar air (a) dan daya berkecambah (b) benih jabon putih dari 8 populasi sebelum penyimpanan $(0$ bulan $)$ dan setelah penyimpanan (54 bulan) (Differences of moisture content and germination capacity of $\underline{\mathrm{N}}$. cadamba seeds from 8 populations before (0 month) and after storage (54 months)

Tabel (Table) 3. Rata-rata keserempakan tumbuh $\left(\mathrm{K}_{\mathrm{ST}}\right)$, kecepatan berkecambah $\left(\mathrm{K}_{\mathrm{CT}}\right)$ dan nilai perkecambahan (NP) benih (rata-rata \pm standard deviasi) dari 8 populasi benih jabon putih (Average of germination uniformity, germination speed, and germination value (mean \pm standard deviation) of $\underline{\mathrm{N}}$. cadamba seeds from 8 populations)

\begin{tabular}{|c|c|c|c|c|c|c|}
\hline \multirow[b]{2}{*}{$\begin{array}{c}\text { Populasi } \\
\text { (Populations) }\end{array}$} & \multicolumn{2}{|c|}{$\mathrm{K}_{\mathrm{ST}}(\%)$} & \multicolumn{2}{|c|}{$\mathrm{K}_{\mathrm{CT}}(\% /$ etmal $)$} & \multicolumn{2}{|c|}{ NP } \\
\hline & $\begin{array}{l}\text { Sebelumsimp } \\
\text { an (Before } \\
\text { storage) } \\
(0 \text { bulan }) \\
(0 \text { month })\end{array}$ & $\begin{array}{c}\text { Setelah simpan } \\
\text { (After storage) } \\
\text { (54 bulan) } \\
(54 \text { months })\end{array}$ & $\begin{array}{l}\text { Sebelum } \\
\text { simpan } \\
(\text { Before } \\
\text { storage }) \\
(0 \text { bulan }) \\
(0 \text { month })\end{array}$ & $\begin{array}{c}\text { Setelah } \\
\text { simpan (After } \\
\text { storage) } \\
\text { (54 bulan) } \\
\text { (54 months) }\end{array}$ & $\begin{array}{l}\text { Sebelumsim } \\
\text { pan (Before } \\
\text { storage }) \\
(0 \text { bulan }) \\
(0 \text { months })\end{array}$ & $\begin{array}{c}\text { Setelah } \\
\text { simpan (After } \\
\text { storage) } \\
(54 \text { bulan }) \\
(54 \text { months })\end{array}$ \\
\hline Kampar & $65,75 \pm 2,99 \mathrm{c}$ & $23,50 \pm 6,66 \mathrm{~d}$ & $5,62 \pm 0,32 \mathrm{~b}$ & $1,61 \pm 0,47 \mathrm{~d}$ & $6,45 \pm 1,40 \mathrm{~b}$ & $0,41 \pm 0,12 \mathrm{de}$ \\
\hline OKI & $47,75 \pm 3,30 \mathrm{e}$ & $2,25 \pm 1,51 \mathrm{e}$ & $3,82 \pm 0,18 \mathrm{~d}$ & $0,15 \pm 0,09 \mathrm{f}$ & $3,00 \pm 0,26 \mathrm{c}$ & $0,01 \pm 0,01 \mathrm{e}$ \\
\hline Garut & $59,75 \pm 3,50 \mathrm{~d}$ & $10,50 \pm 0,58 \mathrm{e}$ & $5,06 \pm 0,28 \mathrm{c}$ & $0,86 \pm 0,06 \mathrm{e}$ & $4,37 \pm 1,43 \mathrm{c}$ & $0,11 \pm 0,57 \mathrm{e}$ \\
\hline $\begin{array}{l}\text { Nusa } \\
\text { Kambangan }\end{array}$ & $64,50 \pm 3,42 \mathrm{c}$ & $4,00 \pm 2,16 \mathrm{e}$ & $5,67 \pm 0,30 \mathrm{~b}$ & $0,27 \pm 0,14 \mathrm{f}$ & $6,47 \pm 1,61 \mathrm{~b}$ & $0,04 \pm 0,03 \mathrm{e}$ \\
\hline Alas Purwo & $51,00 \pm 2,83 \mathrm{e}$ & $35,25 \pm 6,70 \mathrm{c}$ & $4,28 \pm 0,20 \mathrm{~d}$ & $2,57 \pm 0,47 \mathrm{c}$ & $3,78 \pm 0,51 \mathrm{c}$ & $1,16 \pm 0,31 \mathrm{c}$ \\
\hline Kapuas & $71,25 \pm 3,86 \mathrm{~b}$ & $33,25 \pm 5,12 \mathrm{c}$ & $6,01 \pm 0,36 \mathrm{~b}$ & $2,44 \pm 0,33 \mathrm{c}$ & $6,39 \pm 1,38 \mathrm{~b}$ & $0,76 \pm 0,24 \mathrm{~cd}$ \\
\hline Batu Hijau & $50,75 \pm 1,50 \mathrm{e}$ & $54,00 \pm 6,06 \mathrm{~b}$ & $4,20 \pm 0,12 \mathrm{~d}$ & $4,48 \pm 0,41 \mathrm{~b}$ & $3,66 \pm 0,32 \mathrm{c}$ & $2,00 \pm 0,68 \mathrm{~b}$ \\
\hline Pomalaa & $82,25 \pm 2,63 a$ & $77,50 \pm 8,54 \mathrm{a}$ & $6,71 \pm 0,51 \mathrm{a}$ & $5,39 \pm 0,62 \mathrm{a}$ & $8,72 \pm 2,11 \mathrm{a}$ & $4,54 \pm 0,81 \mathrm{a}$ \\
\hline
\end{tabular}

Keterangan (Remarks) : Angka rata-rata yang diikuti oleh huruf sama menunjukkan bahwa nilai rata-rata tidak berbeda nyata pada tingkat nyata $5 \%$ (Means followed by the same letters showed that mean are not significantly different at level of 5\%)

Perbedaan sangat nyata juga ditunjukkan untuk parameter keserampakan tumbuh, kecepatan tumbuh dan nilai perkecambahan antar populasi benih (Tabel 3). Sebelum penyimpanan dan setelah pe- nyimpanan, benih yang berasal dari Pomalaa memiliki nilai parameter perkecambahan yang lebih tinggi di-bandingkan dengan asal benih yang lain. Sebaliknya, benih yang berasal dari Ogan Kemiring Ilir memiliki 


\section{Daya Simpan Benih Jabon Putih [Neolamarckia cadamba (Roxb.) Bosser] \\ Berdasarkan Populasi Dan Karakteristik Benih}

Evayusvita Rustam, Tatiek K. Suharsi, M. Rahmad Suhartanto, dan Dede J. Sudrajat

daya berke-cambah ter kecil (sebelum dan setelah disimpan). Untuk parameter rata-rata waktu yang dibutuhkan untuk berke-cambah benih jabon putih sebelum disimpan tidak berbeda nyata antar populasi asal benih yaitu membutuhkan rata-rata 13 hari, sementara setelah penyimpanan rata-rata waktu untuk berkecambah menunjukkan nilai yang berbeda nyata. Benih yang berasal dari Pomalaa memiliki waktu rata-rata yang dibutuhkan untuk berkecambah 15 hari sementara asal lain mencapai 20 hari (Gambar 3).

\section{Korelasi viabilitas dan vigor benih dengan parameter tempat tumbuh dan karakteristik benih}

Sebagian besar parameter geo-klimat dan unsur makro tapak populasi tidak berkorelasi nyata dengan parameter viabilitas benih sebelum dan setelah disimpan, kecuali letak Bujur yang berkorelasi positif dengan semua parameter perkecambahan benih jabon putih setelah disimpan (Tabel 4). Garis Bujur me-nunjukkan korelasi positif terhadap daya berkecambah $(0,83)$, keserempakan tum-buh $(0,83)$, nilai perkecambahan $(0,82)$ dan berkorelasi negatif terhadap rata-rata waktu berkecambah $(-0,71)$ setelah penyimpanan 54 bulan. Hal yang sama juga ditunjukkan oleh karakter morfo-fisiologis benih, sebagian besar karakter tidak menunjukkan korelasi yang nyata dengan karakter perkecambahan benih sebelum dan setelah penyimpanan benih. Namun beberapa ka-rakter seperti berat 1.000 butir benih berkorelasi negatif terhadap rata-rata waktu berkecambah $(-0,74)$ sebelum disimpan. Korelasi positif antara berat 1.000 butir benih juga terjadi dengan daya berke-cambah $(0,75)$, keserempakan tumbuh $(0,75)$, kecepatan berkecambah $(0,77)$ dan nilai perkecambahan benih $(0,71)$ setelah penyimpanan (Tabel 4). Parameter karakteristik biokimia benih, seperti karbohidrat dan lemak tidak menunjukkan korelasi nyata untuk viabilitas dan vigor benih setelah disimpan. Namun, untuk benih sebelum disimpan, karbohidrat ber-korelasi positif dengan daya berkecambah $(0,77)$, keserempakan tumbuh $(0,72)$ dan kecepatan berkecambah benih $(0,75)$. Pro-tein berkorelasi positif terhadap rata-rata waktu berkecambah benih setelah penyim-panan $(0,82)$ serta berkorelasi negatif dengan daya berkecambah $(-0,93)$, keserempakan tumbuh dan kecepatan tumbuh $(-0,94)$ setelah benih disimpan. Kadar air benih sebelum penyimpanan berkorelasi negatif dengan nilai perkecambahan benih setelah disimpan ($0,85)$.

\section{B. Pembahasan \\ 1. Viabilitas dan vigor benih jabon putih}

Perbedaan asal benih atau populasi jabon putih berpengaruh terhadap daya simpan benihnya. Benih dari populasi Pomalaa (Sulawesi Tenggara) mempunyai karakteristik perkecambahan (daya berkecambah, keserempakan tumbuh, kecepatan berkecambah, dan nilai perkecambahan) terbaik, baik sebelum mau-pun setelah disimpan. Sementara itu, benih dari Ogan Komiring Ilir (Sumatera Selatan) mempunyai karakteristik per-kecambahan benih terendah. Selama penyimpanan, kadar air benih mengalami penurunan dari kisaran 5,58-7,52\% menjadi 3,98-6,27\%. Penurunan kadar air benih selama penyimpanan terjadi juga penyimpanan benih Jatropa curcas (Duong, Shen, Luangviriyasaeng, \& Pinyopusarerk, 2013). Benih bersifat higroskopis; benih dapat menyerap dan melepaskan air dari dan ke lingkungan sekitarnya. Benih mampu mengabsorbsi atau melepaskan hingga tercapai keseimbangan dengan lingkungan sekitarnya (Shelar et al., 2008) Pada penelitian ini, penurunan kadar air terendah terjadi pada benih asal Pomalaa yang memiliki kadar air awal paling rendah (5,58\%). Menurut Jyoti \& Malik (2013), kadar air benih yang rendah mampu meningkatkan daya simpan benih lebih lama. Hal ini ditunjukkan oleh benih dari Pomalaa yang memiliki daya berkecambah benih paling tinggi (79\%) setelah disimpan 54 bulan. Dilihat dari tingkat kadar air dan daya berkecambah, benih jabon putih dapat dikategorikan benih ortodok. Menurut Duong et al. (2013), benih ortodok dapat dikeringkan pada kadar air rendah (2-6\%) tanpa kerusakan dengan daya simpan yang lama pada lingkungan penyimpanan kering dan dingin. 
Benih jabon putih mengalami penurunan vigor setelah disimpan selama 54 bulan. Hal ini bisa dilihat dari penurunan keserempakan tumbuh, kecepat-an berkecambah, dan nilai perkecambahan yang lebih rendah pada benih-benih yang telah disimpan. Daya simpan benih di-pengaruhi oleh karakteristik genetik dan dipengaruhi juga oleh kualitas benih pada saat penyimpanan, tingkat kemasakan benih, riwayat benih sebelum disimpan, kadar air benih, kondisi penyimpanan (suhu dan kelembaban), lama penyimpanan dan agenagen biotik (Shelar et al., 2008; Khatun, Kabir \& Bhuiyan, 2009; Biabani, Boggs, Katozi, \& Sabouri, 2011; Oktaviani, 2012; Sudrajat, \& Nurhasybi, 2016). Benih dari populasi Batu Hijau tidak mengalami penurunan daya ber-kecambah selama penyimpanan, sedangkan benih yang berasal dari Pomalaa mengalami penurunan viabilitas dan vigor yang relatif lebih rendah dibandingkan dengan benih dari populasi lainnya. Benih dari populasi-populasi lainnya seperti Kampar, Ogan Kemiring Ilir, Garut, Nusa Kambangan dan Kapuas mengalami penurunan parameter-parameter perkecambahan yang cukup besar. Secara morfologi benih dari Batu Hijau dan Pomalaa memiliki ukuran dan berat yang lebih tinggi, kandungan biokimia benih (lemak, protein, karbohidrat) yang lebih tinggi (Lampiran 1 dan 2) serta kadar air awal yang relatif rendah sehingga memung-kinkan mempunyai daya simpan yang lebih tinggi. Hal ini memberi indikasi adanya keragaman daya simpan yang cukup tinggi antar populasi jabon putih. Keragaman daya simpan benih dari beberapa populasi juga terjadi pada Swertia chirayita (Pradhan, \& Badola, 2012). Dari delapan populasi yang diuji, benih dari Pomalaa memiliki mutu fisiologis (viabilitas, vigor, dan daya simpan) yang tinggi dengan parameter-parameter perkecamabah benih tertinggi pada benih sebelum dan setelah disimpan, yang diikuti oleh benih dari Batu Hijau.

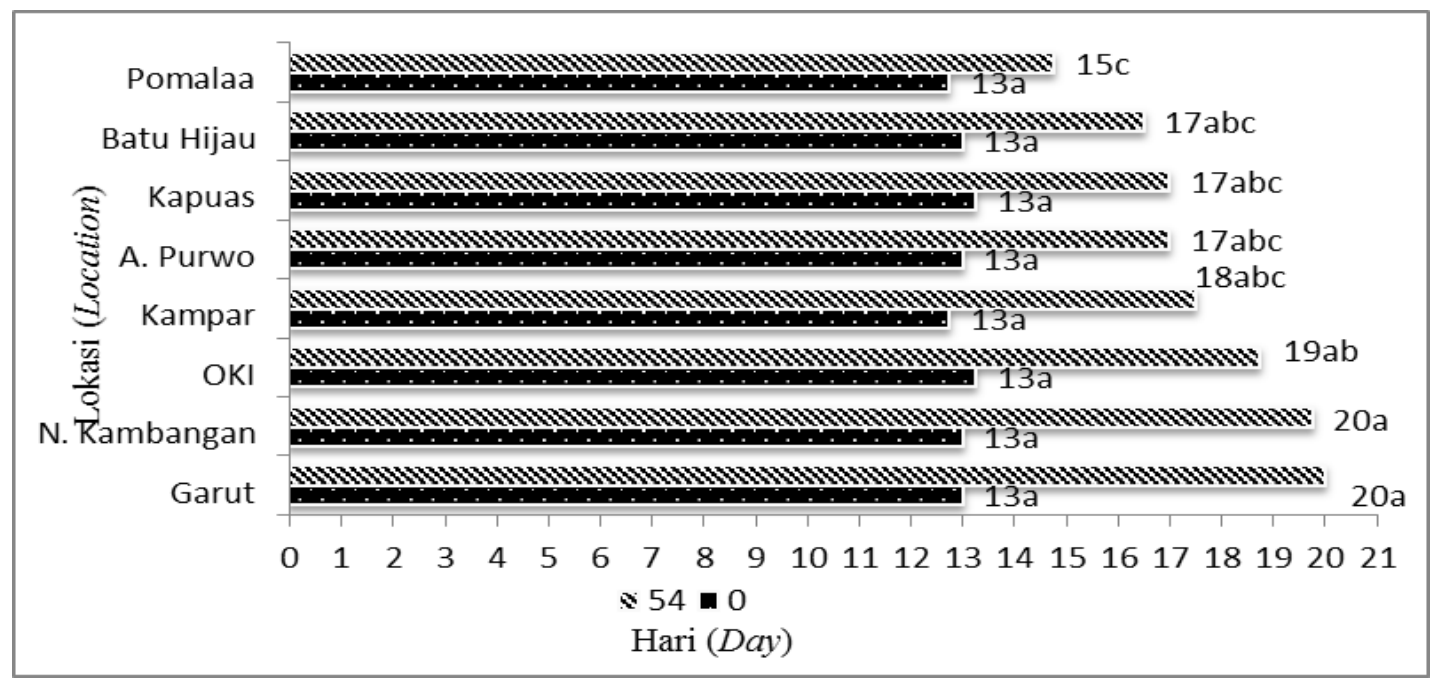

Keterangan (Remark): Angka rata-rata yang diikuti oleh huruf sama menunjukkan bahwa nilai rata-rata tidak berbeda nyata pada tingkat nyata 5\% (Remark: means followed by the same letters showed that mean are not significantly different at level 5\%)

Gambar (Figure) 3. Rata-rata hari yang dibutuhkan untuk berkecambah benih jabon putih sebelum disimpan ( 0 bulan) dan setelah disimpan (54 bulan) (Time required for germination of $\underline{\mathrm{N}}$. cadamba seeds before (0 month) and after storage (54 months) 


\section{Daya Simpan Benih Jabon Putih [Neolamarckia cadamba (Roxb.) Bosser] Berdasarkan Populasi Dan Karakteristik Benih}

Evayusvita Rustam, Tatiek K. Suharsi, M. Rahmad Suhartanto, dan Dede J. Sudrajat

Tabel (Table) 4. Korelasi antar geo-klimat, unsur makro tanah, karakteristik morfofisiologi benih dengan viabilitas dan vigor benih jabon putih sebelum dan setelah disimpan (Correlation between geo-climate, soil macro nutrients, seed morpho-physical traits with viability and vigor of white jabon seeds before and after storage)

\begin{tabular}{|c|c|c|c|c|c|c|c|c|c|c|}
\hline & \multicolumn{5}{|c|}{ Sebelum disimpan (Before storage) } & \multicolumn{5}{|c|}{ Setelah disimpan (After storage) } \\
\hline & Dba & KSTa & $\mathrm{KCTa}$ & RWBa & $\mathrm{NPa}$ & DBs & KSTs & $\mathrm{KCTs}$ & RWBs & NPs \\
\hline Lintang (Latitude) & $-0,34$ & $-0,45$ & $-0,14$ & $-0,15$ & $-0,42$ & 0,10 & 0,03 & 0,10 & 0,20 & 0,06 \\
\hline Bujur (Longitude) & 0,43 & 0,35 & 0,53 & $-0,24$ & 0,31 & $0,83 *$ & $0,83 *$ & $0,84 * *$ & $-0,71 *$ & $0,82 *$ \\
\hline $\begin{array}{l}\text { Ketinggian } \\
\text { tempat (Altitude) }\end{array}$ & 0,15 & 0,22 & 0,08 & 0,02 & 0,05 & $-0,05$ & $-0,06$ & $-0,07$ & 0,31 & $-0,02$ \\
\hline $\begin{array}{l}\text { Curah hujan } \\
\text { (Precipitation) }\end{array}$ & 0,16 & 0,11 & 0,12 & 0,34 & 0,07 & $-0,46$ & $-0,48$ & $-0,47$ & 0,40 & $-0,57$ \\
\hline $\begin{array}{l}\text { Suhu } \\
\text { (Temperature) }\end{array}$ & 0,16 & $-0,02$ & 0,33 & 0,07 & $-0,02$ & 0,57 & 0,51 & 0,56 & $-0,46$ & 0,39 \\
\hline $\mathrm{pH} \mathrm{H} \mathrm{H}_{2} \mathrm{O}$ & $-0,13$ & $-0,01$ & $-0,07$ & $-0,27$ & 0,00 & $-0,21$ & $-0,22$ & $-0,22$ & 0,38 & 0,00 \\
\hline $\begin{array}{l}\text { C-Organik } \\
\text { (C-organic) }\end{array}$ & 0,46 & 0,53 & 0,27 & 0,23 & 0,52 & 0,05 & 0,12 & $-0,06$ & $-0,10$ & 0,24 \\
\hline N-Total & 0,32 & 0,40 & 0,14 & 0,35 & 0,37 & $-0,28$ & $-0,21$ & $-0,26$ & 0,28 & 0,04 \\
\hline $\begin{array}{l}\text { P-tersedia } \\
(P \text {-available })\end{array}$ & $-0,16$ & $-0,41$ & 0,21 & $-0,28$ & $-0,37$ & 0,57 & 0,48 & 0,57 & $-0,39$ & 0,33 \\
\hline $\mathrm{K}$ & $-0,46$ & $-0,50$ & $-0,36$ & 0,33 & $-0,50$ & 0,25 & 0,20 & 0,24 & $-0,27$ & 0,13 \\
\hline $\mathrm{Ca}$ & $-0,29$ & $-0,31$ & $-0,23$ & $-0,04$ & $-0,19$ & $-0,24$ & $-0,24$ & $-0,22$ & 0,33 & $-0,11$ \\
\hline $\mathrm{Mg}$ & $-0,39$ & $-0,35$ & $-0,34$ & $-0,18$ & $-0,28$ & 0,02 & 0,02 & 0,03 & 0,10 & 0,13 \\
\hline $\begin{array}{l}\text { Panjang benih } \\
\text { (Seed length) }\end{array}$ & 0,29 & 0,03 & 0,51 & 0,01 & $-0,01$ & 0,36 & 0,26 & 0,34 & $-0,03$ & 0,22 \\
\hline $\begin{array}{l}\text { Lebar benih } \\
\text { (Seed width) }\end{array}$ & $-0,49$ & $-0,59$ & $-0,32$ & $-0,28$ & $-0,42$ & $-0,13$ & $-0,19$ & $-0,14$ & 0,12 & $-0,07$ \\
\hline $\begin{array}{l}\text { Berat benih } \\
\text { (Seed weight) }\end{array}$ & 0,45 & 0,30 & 0,66 & $0,74 *$ & 0,37 & $0,75^{*}$ & $0,75^{*}$ & $0,77^{*}$ & $-0,59$ & $0,71 *$ \\
\hline $\begin{array}{l}\text { Karbohidrat } \\
\text { (Carbohydrate) }\end{array}$ & $0,77 *$ & $0,72 *$ & $0,75^{*}$ & $-0,52$ & 0,66 & 0,61 & 0,62 & 0,60 & $-0,35$ & 0,40 \\
\hline Lemak $(F a t)$ & $-0,41$ & $-0,56$ & $-0,11$ & $-0,08$ & $-0,51$ & 0,36 & 0,30 & 0,37 & $-0,39$ & 0,05 \\
\hline Protein (Proteine) & 0,36 & 0,24 & 0,56 & 0,48 & 0,22 & $0,93 * *$ & $0,92 * *$ & $0,94 * *$ & $0,79 *$ & 0,51 \\
\hline $\begin{array}{l}\text { Kadar air benih } \\
\text { (Seed masture } \\
\text { content) }\end{array}$ & - & - & - & - & - & $-0,58$ & $-0,65$ & $-0,61$ & 0,56 & $-0,85^{*}$ \\
\hline $\mathrm{DBa}$ & - & - & - & - & - & 0,51 & 0,56 & 0,51 & $-0,46$ & 0,57 \\
\hline KSTa & - & - & - & - & - & 0,39 & 0,47 & 0,40 & $-0,42$ & 0,54 \\
\hline КСТа & - & - & - & - & - & 0,66 & 0,67 & 0,66 & $-0,53$ & 0,62 \\
\hline RWBa & - & - & - & - & - & $-0,57$ & $-0,59$ & $-0,57$ & 0,46 & $-0,60$ \\
\hline $\mathrm{NPa}$ & - & - & - & - & - & 0,37 & 0,46 & 0,38 & $-0,42$ & 0,53 \\
\hline
\end{tabular}

Keterangan (Remarks) : $\mathrm{DBa}=$ Daya berkecambah sebelum di simpan (Germination capacity before storage), $\mathrm{K}_{\mathrm{STa}}=$ Keserempakan tumbuh sebelum disimpan (Germination uniformity before storage), $\mathrm{K}_{\mathrm{c}} \mathrm{a}=$ Kecepatan tumbuh sebelum disimpan (Germination speed before storage), RWBa $=$ Rata-rata waktu berkecambah sebelum disimpan (Mean of germination time before storage), $\mathrm{NPa}=$ Nilai perkecambahan sebelum disimpan (Germination value before storage), DBs = Daya berkecambah setelah disimpan (Germination capacity after storage), KsTs = Keserempakan tumbuh setelah disimpan (Germination uniformity after storage), $\mathrm{K}_{\mathrm{CTS}}=$ Kecepatan tumbuh setelah disimpan (Germination speed after storage), RWBs = Rata-rata waktu berkecambah setelah disimpan (Mean of germination time after storage), NPs = Nilai perkecambahan setelah disimpan (Germination value after storage), $* *=$ Berkorelasi nyata pada tingkat nyata $1 \%$ (Significant at level of 1\%), * = Berkorelasi nyata pada tingkat nyata $5 \%$ (Significant at level of $5 \%)$ 


\section{Korelasi viabilitas dan vigor benih dengan parameter geo-klimat tempat tumbuh dan karakteristik benih}

Faktor geo-klimat yang berkorelasi nyata dengan karakteristik perkecambahan benih jabon putih adalah garis Bujur dengan daya berkecambah, keserempakan tumbuh, kecepatan berkecambah, ratarata waktu berkecambah dan nilai perkecam-bahan. Secara umum, kondisi geo-klimat dan unsur makro tanah asal benih sebagian besar tidak berkorelasi nyata dengan karakteristik perkecambahan benih jabon putih sebelum dan setelah penyimpanan. Perkecambahan dan daya simpan benih merupakan karakter yang dikendalikan secara genetik, dipengaruhi oleh kondisi benih sebelum disimpan dan kondisi lingkungan penyimpanan (Jyoti, \& Malik, 2013). Sudrajat (2016) menyatakan bahwa perkecambahan benih jabon putih dari sebelas populasi di Indonesia sangat dipengaruhi faktor genetik dibandingkan dengan lingkungan tempat tumbuhnya. Kontribusi faktor genetik terhadap karak-teristik perkecamabahan benih yang lebih besar dibandingkan faktor lingkungan pada Pongamia pinnata (Divakara, Alur, \& Tripati, 2010) dan pada jenis Pinus wallichiana (Rawat, \& Bakshi, 2011).

Karakteritik morfologi benih juga sebagian besar tidak memberikan korelasi nyata dengan karakteristik perkecambahan benih, kecuai berat benih. Karakter berat benih berkorelasi positif antara rata-rata waktu berkecambah benih sebelum disimpan dengan daya berkecambahan, keserempakan tumbuh dan kecepatan berkecambahan benih setelah disipun. Hal ini terjadi juga pada jenis Pongamia pinnata, berat benih berkorelasi positif dengan perkecambahan benih (Divakara et al., 2010) sehingga karakter berat benih merupakan karakter penting untuk seleksi benih dengan daya berkecambah tinggi. Untuk kandungan biokimia benih, karbohidrat berkorelasi positif dengan daya berkecambah, keserempatan tumbuh dan kecepatan tumbuh benih segar (sebelum disimpan). Karbohidrat berperan sebagai sumber energi utama dalam perkecam-bahan benih. Karbohidrat akan terhidrolisis oleh $\alpha$ dan $\beta$-amylase dengan perantara giberelin menjadi maltose dan glukosa. Metabolisme glukosa dilakukan dengan glikolisis yang membentuk asam pyruvat dan aAdenosine tTrifphosfat (ATP) dan oksidasi melalui siklus Krebs. Asam pyruvat dan ATP merupakan sumber energi utama dalam perkecambahan benih. Secara umum, sejalan dengan periode penyimpanan, kandungan cadangan makanan (karbohidrat) akan menurun yang diikuti dengan menurunnya daya ber-kecambah (Hartawan, Djafar, Negara, Hasmeda, \& Zulkanaen, 2011) yang diduga terjadi pula pada penyimpanan benih jabon putih pada penelitian ini. Kandungan karbohidrat awal yang tinggi memungkinkan benih mampu disimpan lebih lama. Kandungan protein juga berkorelasi positif dengan daya berkecambah, keserempakan tumbuh, dan kecepatan berkecambah. Hal ini disebabkan kandungan protein yang tinggi pada membran sel akan meningkatkan integritas membran sel sehingga tidak mudah terjadi kebocoran (Hartawawan, \& Nengsih, 2012). Korelasi juga terjadi antara kadar air benih dengan nilai per-kecambahan benih setelah penyimpanan yang bernilai negatif. Kadar air yang lebih rendah memungkinkan daya simpan benih semakin tinggi yang dicirikan dengan nilai perkecambahan benih jabon putih setelah penyimpanan yang tinggi.

Pada penelitian ini, kondisi perkecambahan awal benih tidak berkorelasi nyata dengan karakteriatik perkecambahan setelah disimpan. Beberapa penelitian menyatakan hal sebaliknya, bahwa viabilitas awal yang tinggi mampu mem- 
pertahankan kualitas benih dalam penyimpanan benih daripada benih dengan daya berkecambah awal rendah (Jyoti, \& Malik, 2013; Sudrajat, \& Nurhasybi, 2016). Namun menurut Shaban (2013), benih dengan daya berkecambah awal yang tinggipun tidak dapat dijadikan jaminan untuk mampu disimpan lama. Hal ini dikarenakan masih banyak faktor lain yang mempengaruhi potensi daya simpan benih, seperti faktor lingkungan dan genetik. Rendahnya korelasi antar faktor lingkungan dengan karakteristik perkecambahan benih jabon putih setelah disimpan, faktor genetik diduga lebih dominan mempengaruhi daya simpan benih masing-masing asal benih/populasi. Jabon putih merupakan jenis dengan sistem perkawinan silang sehingga mempengaruhi sistem penyerbukan dan kualitas benih yang dihasilkan, populasi yang berukuran besar seperti benih yang berasal dari pupulasi Pomalaa dan dari Batu Hijau memung-kinkan mempunyai keragaman yang tinggi (Sudrajat et al., 2015).

\section{KESIMPULAN DAN SARAN}

\section{A. Kesimpulan}

Asal benih jabon putih telah mempengaruhi perkecambahan benih baik sebelum dan setelah disimpan selama 54 bulan. Karakteristik perkecambahan benih yang terbaik berasal dari populasi Pomalaa (Sulawesi Tenggara) yaitu daya ber-kecambah benih jabon putih sebelum disimpan sebesar $82,75 \%$ dan setelah disimpan 54 bulan menjadi 79\%. Namun karaketristik perkecambahannya yang terendah berasal dari Ogan Kemiring Ilir (Sumatera Selatan), yaitu $48,75 \%$ sebelum disimpan dan menjadi 2,5\% setelah disimpan 54 bulan. Asal benih dari populasi Batu Hijau daya berkecambah benihnya mengalami peningkatan $3,5 \%$ dari daya berkecambah awal. Dengan demikian, benih jabon putih bisa dikategorikan benih ortodok yaitu mampu disimpan dalam waktu yang lama (sampai 54 bulan) pada temperatur dan kadar air rendah. Sebagian besar faktor geo-klimat dan unsur makro tanah tidak berkorelasi secara nyata dengan perkecambahan benih baik sebelum maupun setelah disimpan. Faktor geo-klimat yang berkorelasi nyata dengan karakteristik perkecambahan benih jabon putih adalah garis Bujur dengan daya berkecambah, keserempakan tumbuh, kecepatan berkecambah, rata-rata waktu berkecambah dan nilai perkecambahan. Diduga faktor genetik berkontribusi besar dalam mempengaruhi perbedaan daya simpan benih jabon putih.

\section{B. Saran}

Untuk meningkatkan produksi bibit direkomendasikan menggunakan sumber benih jabon putih dari Pomalaa (Sulawesi Tenggara) dan benih disimpan tidak lebih dari 54 bulan.

\section{UCAPAN TERIMA KASIH}

Ucapan terima kasih disampaikan kepada PT. Vale Indonesia (Pomalaa, Sulawesi Tenggara), PT. Newmont Indonesia (Batu Hijau, Sumbawa), PT. Dasa Intiga (Kapuas, Kalimantan Tengah), BKSDA Jawa Tengah, Taman Nasional Alas Purwo, dan SEAMEO BIOTROP atas bantuan akomodasi selama pengumpulan sampel benih jabon putih.

\section{DAFTAR PUSTAKA}

Acharyya, S., Rathore, D.S., Kumar H.K.S., \& P.N. (2011). Screening of Anthocephalus cadamba (Roxb.) Miq. root for antimicrobial and anthelmintic activities. International Journal of Research in 
Pharmaceutical and Biomedical Sciences, 2(1), 297-300.

Biabani, A., Boggs, L.C., Katozi M., \& Sabouri, H. (2011). Effects of seed deterioration and inoculation with Mesorhizobium ciceri on yield and plant performance of chickpea, 5(1), $66-70$

Cruz, V.M.V., Walters, C.T., \& Dierig, D.A. (2013). Dormancy and afterripening response of seeds from natural populations and conserved Physaria (syn. Lesquerella) germplasm and their association with environmental and plant parameters. Industrial Crops \& Products, 45, 191-199.

Divakara, B.N., Alur A.S., \& Tripati, S. (2010). Genetic variability and relationship of pod and seed traits in Pongamia pinnata (L.) Pierre., a potential agroforestry tree. International Journal of Plant Production, 4(2), 129-141.

Duong, T.H., Shen, J.L., Luangviriyasaeng, V., Ha, H.T., \& Pinyopusarerk, K. (2013). Storage behaviour of Jatropha curcas seeds. Journal of Tropical Forest Science, 25(2), 193-199.

Eshun, G., Amankwah, E.A., \& Barimah, J. (2013). Nutrients content and lipid characterization of seed pastes of four selected peanut (Arachis hypogaea) varieties from Ghana. African Journal of Food Science,7(10), 375-381.

Gairola, K.C., Nautiyal, A.R., \& Dwivedi, A.K. (2011). Effect of temperatures and germination media on seed germination of Jatropha curcas Linn. Advances In Bioresearch, 2(2), 66-71.

Hartawan, R., Djafar, Z.R., Negara, Z.P., Hasmeda, M., \& Zulkanaen. (2011). Pengaruh panjang hari, asam indol asetat, dan fosfor terhadap tanaman kedelai dan kualitas benih dalam penyimpanan. Jurnal Agronomi Indonesia, 39(1), 7-12.

Hartawawan, R., \& Nengsih, Y. (2012). Kadar air dan Karbohidrat berperan dalam mempertahankan kualitas benih karet. Agrovigor, 5(2), 103112.

ISTA (International Seed Testing Association). (2012). International rules for seed testing: Edition 2012. International Seed Testing Assosiation. Bassersdorf. $\mathrm{CH}-$ Switzerland.

Irawan, U.S., \& Purwanto, E. (2014). White jabon (Anthocephalus cadamba) and red jabon (Anthocephalus macrophyllus) for community land rehabilitation: Improving local provagation efforts. Agricultural Science, 2(3), 36-45.

Jyoti, \& Malik, C.P. (2013). Seed deterioration: A review. International Journal of Life Sciences Biotechnology and Pharma Research, 2(3), 374-385.

Kallio, M.H., Krisnawati, H., Rohadi, D., \& Kanninen, M. (2011). Mahogany and kadam planting farmers in South Kalimantan: The link between silvicultural activity and stand quality. Small-scale Forestry, 10, 115-132.

Khatun, A., Kabir, G., \& Bhuiyan, M.A.H. (2009). Effect of harvesting stages on the seed quality of lentil (Lens culinaris L.) during storage. Bangladesh J. Agril. Res, 34(4), 565-576.

Krisnawati, H., Kallio, M., \& Kanninen, M. (2011). Anthocephalus cadamba Miq. : ekologi, silvikultur dan produktivitas. Bogor (ID): Center for International Forestry Research, Bogor.

Mansur, I. (2012). Prospek 
pengembangan jabon untuk mendukung pengembangan hutan tanaman. Prosiding. Prospek Pengembangan Hutan Tanaman (Rakyat), Konservasi, dan Rehabilitas Hutan. Manado, Indonesia. Manado (ID). Balai Penelitian Kehutanan Manado.

Mishra, R.P., \& Siddique, L. (2011). Antibacterial properties of Anthocephalus cadamba fruits. Asian Journal of Plant Science and Rsearch, 1(2), 1-7.

Oktaviani, K.A. (2012). Studi genetik terhadap daya simpan benih kedelai hitam (Glycine $\max$ (L.) Merr.) Fakultas Pertanian. Bogor. Institut Peranian Bogor.

Pradhan, B.K., \& Badola, H.K. (2012). Effect of storage conditions and storage periods on seed germination in eleven populations of Swertia chirayita: A critically endangered medicinal herb in Himalaya. The Scientific World Journal.1-9. DOI: 10.1100/2012/128105.

Rawat, K., \& Bakshi, M. (2011). Provenance variation in cone, seed and seedling characteristics in natural populations of Pinus wallichiana A. B. Jacks (Blue Pine) in India. Annals of Forest Resesarch, 54(1), 39-55.

Shaban, M. (2013). Review on physiological aspects of seed deterioration. International Journal of Agriculture Crop Science, 6(11), 627-631.

Shelar, V.R., Shaikh, R.S., \& Nikam, A.S. (2008). Soybean seed quality during storage: A Review. Agriculture Review, 29(2), 125-131.

Sudrajat, D.J. (2013). Perbenihan dan genetika jabon. Seminar Teknologi Budidaya dan Pemanfaatan Kayu Jabon dalam rangka Dies Natalis
IPB ke-50. Bogor. Institut Pertanian Bogor.

Sudrajat, D.J. (2015). Keragaman populasi, uji provenansi dan adaptasi jabon (Neolamarckia cadamba (Roxb.) Bosser). Disertasi. Sekolah Pascasarjana. Institut Pertanian Bogor.

Sudrajat, D.J. (2016). Genetic variation of fruit, seed and seedling characteristics among 11 populations of white jabon in Indonesia. Forest Science and Technology, 12(1), 9-15.

Sudrajat, D.J., \& Nurhasybi. (2016). Daya simpan benih suren (Toona sinensis) dalam hubungannya dengan karakteristik tempat tumbuh asal benih dan morfo-biokimia benih. Proseding Seminar Nasional Silvikultur IV, 19-20 Juli 2016. Samarinda: Universitas Mulawarman.

Sudrajat, D.J., Siregar, I.Z., Khumaida, N., Siregar, U.J., \& Mansur, I. (2015). Genetic diversity of white jabon (Anthocephalus cadamba Miq.) based on AFLP markers. Asia Pasific Journal of Molecular Biology and Biotechnology, 2(3), 224-231.

Suszka, J., Plitta, B.P., \& Michalak, M. (2014). Optimal seed water content and storage temperature for preservation of Populus nigra L. germplasm. Annals of Forest Science, 71, 543-549. DOI: 10.1007/s13595-014-0368-2.

Yasaka, M., Takiya, M., \& Watanabe, I. (2008). Variation in seed production among years and among individuals in 11 broadleaf tree species in Northern Japan. Journal Forest Research, 13, 83-88. 
Yuniarti, N., \& Nurhasybi, N. (2015). Viability and biochemical content changes in seed storage of jabon putih (Anthocephalus cadamba (Roxb) Miq.). Jurnal Manajemen Hutan Tropika, 21(2), 92-98. DOI: 10.7226/jtfm.21.2.92.

Yuniarti, N., Kurniaty, R., \& Nurhasybi. (2015). Perkecambahan, pembibitan, standar mutu benih dan bibit jabon putih. Bunga Rampai. Teknologi Perbenihan Jabon Putih [Neolamarckia cadamba (Roxb.) Bosser]. FORDA PRESS. 81-106. 


\section{Daya Simpan Benih Jabon Putih [Neolamarckia cadamba (Roxb.) Bosser] Berdasarkan Populasi Dan Karakteristik Benih}

Evayusvita Rustam, Tatiek K. Suharsi, M. Rahmad Suhartanto, dan Dede J. Sudrajat

Lampiran (Appendix) 1. Karakteristik morfologi buah dan benih jabon putih dari 8 populasi (Morphological characteristics of fruits and seeds white jabon from 8 populations)

\begin{tabular}{lccc}
\hline Populasi (Populations) & $\begin{array}{c}\text { Panjang benih } \\
(\text { Seed length }) \\
(\mu \mathrm{m})\end{array}$ & $\begin{array}{c}\text { Lebar benih } \\
(\text { Seed width }) \\
(\mu \mathrm{m})\end{array}$ & $\begin{array}{c}\text { Berat 1.000 } \\
\text { butir }(\text { Weight } \\
\text { of 1,000 seed }) \\
(\mathrm{mg})\end{array}$ \\
\hline Kampar (Riau) & $567,4 \pm 54,0$ & $434,7 \pm 64,4$ & $39,3 \pm 1,0$ \\
Ogan Kemiring Ilir (Sumatera Selatan) & $566,8 \pm 43,2$ & $408,7 \pm 59,4$ & $37,0 \pm 0,3$ \\
Garut (Jawa Barat) & $596,3 \pm 67,7$ & $404,6 \pm 55,1$ & $37,7 \pm 0,3$ \\
Nusa Kambangan (Jawa Tengah) & $604,8 \pm 51,1$ & $440,5 \pm 66,5$ & $40,3 \pm 1,6$ \\
Alas Purwo (Jawa Timur) & $584,4 \pm 88,8$ & $459,4 \pm 72,2$ & $37,7 \pm 0,1$ \\
Kapuas (Kalimantan Tengah) & $607,5 \pm 75,9$ & $388,3 \pm 40,3$ & $35,8 \pm 0,3$ \\
Batu Hijau (Nusa Tenggara Barat) & $623,9 \pm 63,2$ & $440,5 \pm 61,3$ & $46,9 \pm 1,9$ \\
Pomalaa (Sulawesi Tengah) & $586,4 \pm 68,7$ & $388,8 \pm 53,9$ & $46,1 \pm 0,9$ \\
\hline
\end{tabular}

Lampiran (Appendix) 2. Kadar lemak, karbohidrat, dan protein benih jabon putih sebelum penyimpanan dari 8 populasi (Fat, carbohydrate, and protein content of white jabon seed before storage from 8 populations)

\begin{tabular}{lccc}
\hline $\begin{array}{c}\text { Populasi } \\
\text { (Populations })\end{array}$ & $\begin{array}{c}\text { Kadar lemak } \\
(\text { Fat content })\end{array}$ & $\begin{array}{c}\text { Kadar karbohidrat } \\
(\text { Carbohydrate content })\end{array}$ & $\begin{array}{c}\text { Kadar protein } \\
(\text { Proteine content }) \\
(\%)\end{array}$ \\
\hline Kampar & 0,50 & 72,55 & 14,88 \\
OKI & 1,24 & 70,76 & 11,39 \\
Garut & 0,05 & 73,75 & 11,04 \\
Nusa Kambangan & 0,14 & 73,05 & 13,70 \\
Alas Purwo & 0,68 & 72,89 & 14,05 \\
Kapuas & 0,16 & 73,42 & 14,53 \\
Batu Hijau & 1,80 & 73,01 & 14,40 \\
Pomalaa & 0,60 & 74,54 & 15,01 \\
\hline
\end{tabular}

Lampiran (Appendix) 3. Unsur hara makro tempat tumbuh 8 populasi jabon putih (Macronutrient of the site of 8 white jabon populations)

\begin{tabular}{lcccrrrrr}
\hline $\begin{array}{c}\text { Populasi } \\
\text { (Populations) }\end{array}$ & $\mathrm{pH} \mathrm{H}_{2} \mathrm{O}$ & $\mathrm{C}$ Organik & $\mathrm{N}$ total & $\begin{array}{c}\text { Nisbah } \\
\mathrm{C} / \mathrm{N}\end{array}$ & P tersedia & $\mathrm{K}$ & $\mathrm{Mg}$ & \multicolumn{1}{c}{$\mathrm{Ca}$} \\
\hline Kampar & 4,4 & 1,10 & 0,13 & 8,5 & 5,47 & 0,15 & 1,20 & 1,76 \\
OKI & 4,7 & 2,82 & 0,35 & 8,1 & 6,86 & 2,44 & 5,20 & 13,16 \\
Garut & 5,1 & 2,25 & 0,31 & 7,3 & 2,47 & 0,98 & 6,26 & 9,26 \\
Nusa & 6,7 & 4,95 & 0,47 & 10,5 & 10,94 & 1,46 & 8,37 & 29,65 \\
Kambangan & 6,0 & 3,16 & 0,18 & 17,6 & 34,18 & 4,00 & 11,41 & 20,15 \\
Alas Purwo & 4,4 & 4,75 & 0,36 & 13,2 & 6,44 & 2,35 & 0,57 & 2,09 \\
Kapuas & 6,4 & 1,64 & 0,17 & 9,6 & 90,28 & 2,78 & 5,86 & 13,78 \\
Tengah & 6,1 & 4,60 & 0,38 & 12,1 & 15,82 & 1,58 & 6,42 & 10,33 \\
Batu Hijau & & & & & & & & \\
Pomalaa & & & & & & &
\end{tabular}

